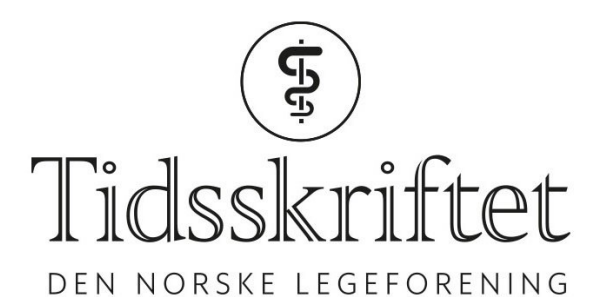

DEN NORSKE LEGEFORENING

\title{
Renal fibromuskulær dysplasi og hypertensjon
}

KLINISK OVERSIKT

\section{MARTIN SOMMER}

E-post: m.s.sommer@studmed.uio.no

Medisinsk fakultet

Universitetet i Oslo

Han har bidratt med idé, datainnsamling, analyse og tolkning av data, litteratursøk og utarbeiding av manuskriptet.

Martin Sommer er medisinstudent.

Forfatteren har fylt ut ICMJE-skjemaet og oppgir ingen interessekonflikter.

\section{NANNA VON DER LIPPE}

Nyremedisinsk avdeling, Medisinsk klinikk

Oslo universitetssykehus, Ullevål

Hun har bidratt med revisjon og godkjenning av innsendt manuskript.

Nanna von der Lippe er ph.d., spesialist i indremedisin og lege i spesialisering i nyresykdommer.

Forfatteren har fylt ut ICMJE-skjemaet og oppgir ingen interessekonflikter.

\section{NILS-EINAR KLØW}

Avdeling for radiologi og nukleærmedisin

Oslo universitetssykehus, Aker og Ullevål

og

Institutt for klinisk medisin

Medisinsk fakultet

Universitetet i Oslo

Han har bidratt med revisjon og godkjenning av innsendt manuskript.

Nils-Einar Kløw er spesialist i radiologi, seksjonsoverlege og professor.

Forfatteren har fylt ut ICMJE-skjemaet og oppgir ingen interessekonflikter.

\section{AUD HØIEGGEN}

Nyremedisinsk avdeling, Medisinsk klinikk, Oslo universitetssykehus, Ullevål og Insititutt for klinisk medisin

Medisinsk fakultet

Universitetet i Oslo

Hun har bidratt med idé og revisjon og godkjenning av innsendt manuskript.

Aud Høieggen er dr.med., spesialist i indremedisin og i nyresykdommer, overlege og

førsteamanuensis.

Forfatteren har fylt ut ICMJE-skjemaet og oppgir ingen interessekonflikter.

Fibromuskulær dysplasi rammer muskulaturen i små og middelsstore arterier. Tilstanden har ukjent etiologi og sees hyppigst hos middelaldrende kvinner, men kan ramme begge kjønn i alle aldre. Ved affeksjon av nyrearteriene er hypertensjon den vanligste kliniske manifestasjonen. Diagnosen stilles på bakgrunn av klinisk mistanke og spesifikke 
angiografiske funn. Behandlingen rettes mot normalisering av blodtrykket ved hjelp av medikamenter eller ved revaskularisering.

Fibromuskulær dysplasi ble første gang beskrevet i 1938 (1). I mangel på vitenskapelige data antok man tidligere at det i hovedsak var nyrearteriene som var affisert, og hos en liten andel pasienter hals- og vertebralarteriene. Tall fra det amerikanske fibromuskulær dysplasi-registeret har bidratt til endret forståelse, da det ble dokumentert at $80 \%$ av pasientene hadde forandringer i nyrearteriene, og $75 \%$ forandringer i precerebrale kar (2). I en nyere studie med 469 pasienter fant man affeksjon av mer enn ett kargebet hos $48 \%$ (3). Symptomgivende tilfeller er også påvist i koronarkar, cerebrale og abdominale kar, og i arterier i over- og underekstremiteter (2). I denne artikkelen fokuserer vi på fibromuskulær dysplasi som årsak til renovaskulær hypertensjon, men vi ønsker å fremheve at sykdommen også kan manifestere seg på andre vis. Artikkelen er basert på et ikke-systematisk litteratursøk i PubMed og på egne kliniske erfaringer.

\section{Epidemiologi}

Symptomatiske manifestasjoner av renal fibromuskulær dysplasi antas å forekomme hos $0,4 \%$ av befolkningen (4). Hos pasienter med hypertensjon estimerer man at nyrearteriestenose foreligger hos 1-2 \%. Av disse har 10-20 \% renal fibromuskulær dysplasi, mens de øvrige har aterosklerotisk sykdom som årsak til nyrearteriestenosen (4). Asymptomatiske tilfeller av renal fibromuskulær dysplasi synes å være hyppigere. I en metaanalyse av potensielle nyredonorer fant man renal fibromuskulær dysplasi hos 2,6\% (5). Resultatene kan diskuteres siden nyredonorer generelt er friskere enn normalbefolkningen, og fordi de radiologiske kriteriene ikke var strengt definert. Tall fra det amerikanske registeret viser at omtrent $90 \%$ av pasientene er kvinner (2). Man har trodd at sykdommen i hovedsak affiserer yngre kvinner i 20-30-årene, men nyere tall viser at gjennomsnittsalder ved diagnose er 51,9 år (2).

\section{Klassifisering}

Uavhengig av kargebet er patologiske forandringer ved fibromuskulær dysplasi funnet i alle tre lag av arterieveggen (tunica intima, media og externa/adventitia; se figur 1 ). Forandringene består av bindevevsdannelse og/eller hyperplasi av glatte muskelceller. I 2012 la en europeisk ekspertgruppe frem en forenklet subklassifisering basert på angiografiske funn: multifokal («string-of-beads»), tubulær (stenoser $\geq 1 \mathrm{~cm}$ lengde) eller unifokal type (stenose $<1 \mathrm{~cm}$ lengde) (6). Siden skillet mellom unifokal og tubulær type var basert på stenosens lengde, ble det anbefalt å samle disse typene under betegnelsen unifokal. Multifokal manifestasjon med alternerende dilatasjon og konstriksjon av arterien utgjør over 80 \% av tilfellene av renal fibromuskulær dysplasi (2). Multifokal type er klassisk for fibromuskulær dysplasi, mens den unifokale kan være vanskeligere å skille fra andre årsaker til karanomalier (figur 2 og 3). I nyrearterien er det uavhengig av subtype de midtre og distale deler av karet som affiseres, og hos $60 \%$ av pasientene er affeksjonen bilateral (4). Aneurismer og disseksjon i nyrearterien kan forårsake nyreinfarkter (7) og er beskrevet hos henholdsvis 5,6\% og 4,3\%(2). 


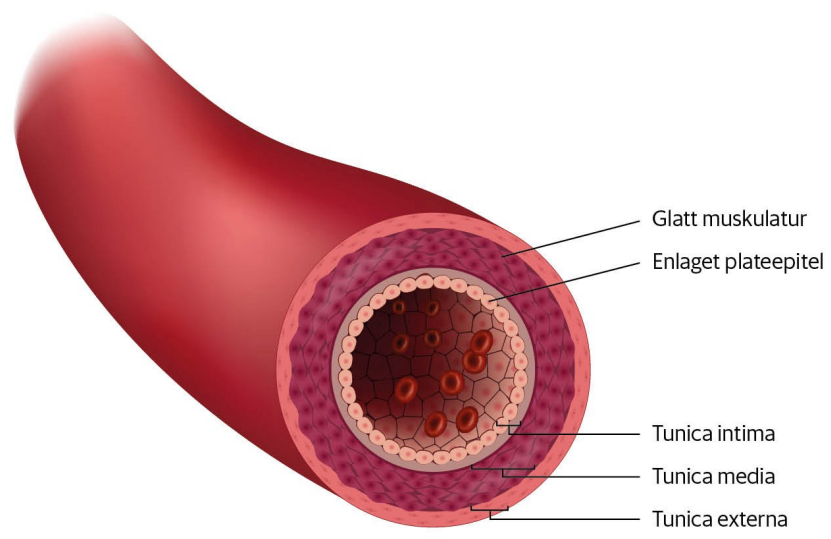

Figur 1 Arterieveggens oppbygning bestående av blant annet tunica intima, media og externa/adventitia. Illustrasjon: tefim/iStock

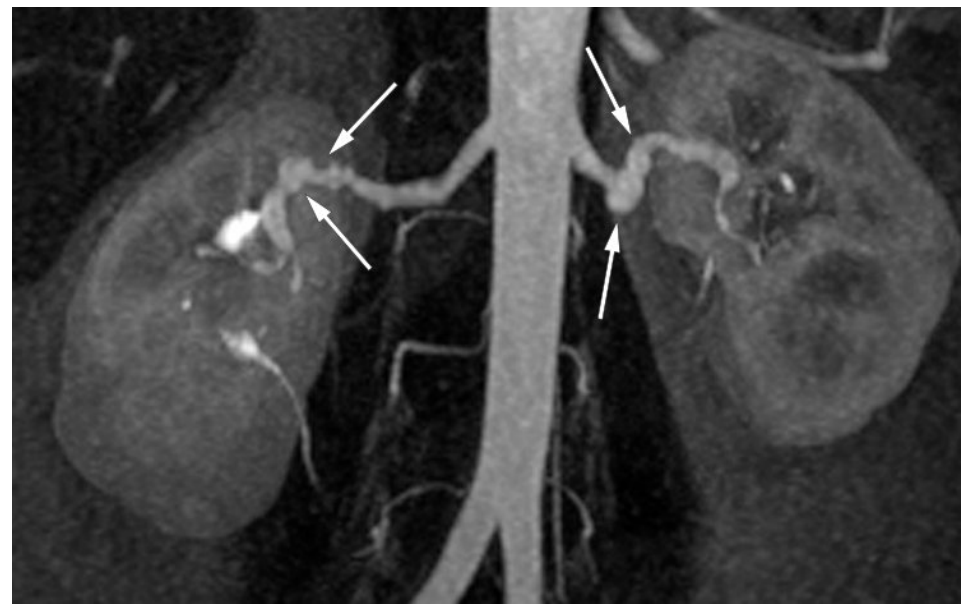

Figur 2 MR-angiografi av nyrearteriene hos en pasient. Bildet viser multifokal fibromuskulcr dysplasi der nyrearteriene har varierende diameter, ektasier og stenoser på begge sider.

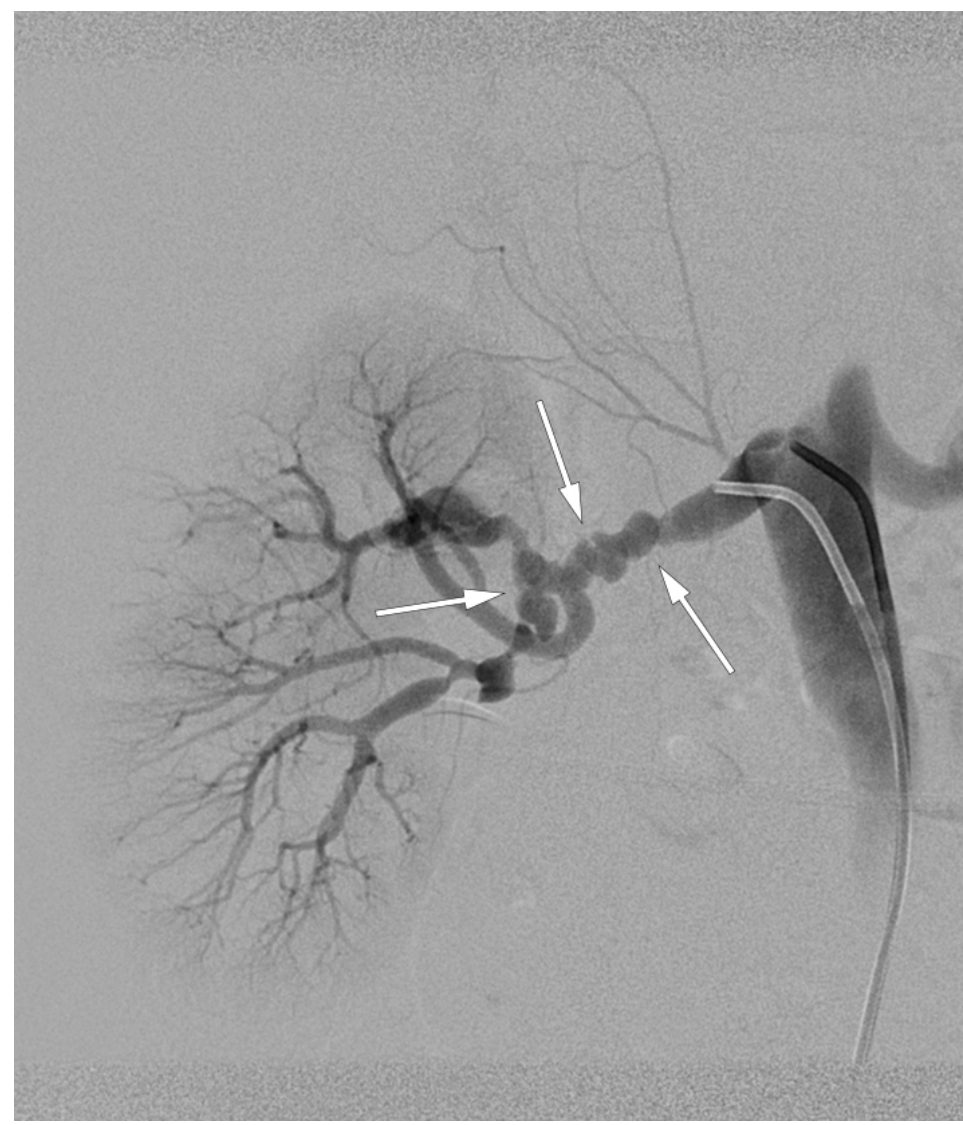

Figur 3 Konvensjonell angiografi av høyre nyrearterie hos en pasient tatt i forbindelse med angioplastikk. Pilene peker på alternerende ektasier og stenoser forenlige med multifokal 


\section{Etiologi og patogenese}

Patogenesen ved fibromuskulær dysplasi er uklar, og både genetikk og miljøfaktorer spiller trolig en rolle. I det amerikanske registeret har $7,3 \%$ av pasientene familiemedlemmer med tilstanden (2). Data antyder at sykdommen følger en autosomal dominant arvegang med variabel penetrans (8). Humant leukocyttantigen (HLA) type DRw6 forekommer hyppigere ved fibromuskulær dysplasi (9). Data som kobler fibromuskulær dysplasi og forandringer i PHACTR1-genet er også presentert. Genet er involvert i angiogenese og cellemigrasjon, og kjent som et risikolocus for utvikling av koronarsykdom, migrene og carotisdisseksjon (10). $\emptyset \mathrm{kt}$ plasmakonsentrasjon av de proinflammatoriske signalmolekylene transformerende vekstfaktor beta-1 og -2 er funnet hos noen pasienter sammenlignet med friske kontrollgrupper (11). Andelen røykere eller tidligere røykere er høyere sammenlignet med kontrollgrupper med essensiell hypertensjon. Røyking er også assosiert med tidligere debut av sykdommen og alvorligere hypertensjon (12). Grunnet høy kvinneandel antar man at østrogenpåvirkning og bruk av hormonpreparater er involvert i utviklingen av fibromuskulær dysplasi (9).

\section{Klinisk presentasjon}

Det vanligste funnet ved renal affeksjon er alvorlig hypertensjon, ofte med debut i ung alder (<40 år), som kan være vanskelig å behandle medikamentelt (2). Hypertensjonen skyldes nedsatt renal perfusjon grunnet stenose av nyrearterien som aktiverer renin-angiotensinaldosteron-systemet, med redusert natriurese, $ø$ kt sympatisk nerveaktivitet og perifer vasokonstriksjon som følge. I motsetning til aterosklerotisk nyrearteriestenose medfører fibromuskulær dysplasi sjelden redusert nyrefunksjon (4). En mulig forklaring på dette kan være at pasientene med fibromuskulær dysplasi er yngre og har mindre uttalt aterosklerose og lavere forekomst av andre risikofaktorer for nedsatt nyrefunksjon, f.eks. diabetes og overvekt.

Ved affeksjon av andre kargebet enn nyrearteriene kan pasientene ha symptomer som smerter i epigastriet, og ved precerebrale og intracerebrale forandringer forekommer hodepine, svimmelhet og i verste fall TIA og hjerneslag (2).

Ved søk på diagnosekoden renovaskulær hypertensjon i Ullevål sykehus sitt elektroniske journalsystem i perioden 2003-18 fant vi 13 pasienter med diagnosen fibromuskulær dysplasi basert på typiske angiografiske funn. Alle hadde blodtrykk over eller lik 140/90 mm Hg og/eller brukte antihypertensiver (1-4 stk.) på diagnosetidspunktet. Vår erfaring er at de fleste pasienter med klinisk signifikant renal fibromuskulær dysplasi har behov for revaskularisering. Blant våre pasienter har 10 av 13 vært normotensive, og like mange har kunnet redusere dosen eller seponere ett eller flere antihypertensiver etter revaskulariserende inngrep.

\section{Diagnostikk}

Det finnes ingen entydige kliniske indikasjoner for når en bør utrede med tanke på renal fibromuskulær dysplasi. En europeisk konsensus anbefaler bildediagnostisk utredning av renovaskulær hypertensjon ved behandlingsresistent hypertensjon hos pasienter under 50 år og ved alvorlig behandlingsresistent hypertensjon uavhengig av alder. I tillegg anbefales slik utredning ved mistanke om fibromuskulær dysplasi i andre karområder, f.eks. halsarterier og koronararterier, samt hos pasienter med høy sannsynlighet for eller påvist spontan koronar arteriedisseksjon (13).

Kateterbasert digital subtraksjonsangiografi er diagnostisk gullstandard (14), men benyttes hovedsakelig som ledd i behandling med angioplastikk. Aktuelle undersøkelsesmetoder er ultralyd med doppler og CT- og MR-angiografi av nyrearteriene. Ultralyd kan påvise økte 
blodhastigheter i nyrearterien og endringer i dopplersignalene i nyrene. Metoden er billig og lite invasiv, men har lav sensitivitet, derfor gjøres ofte CT- og MR-angiografi, som har høyere sensitivitet og spesifisitet $(15,16)$, spesielt for multifokal fibromuskulær dysplasi (17).

CT-angiografi er mer presis og har bedre oppløsning enn MR-angiografi, spesielt ved lesjoner distalt i nyrearterien og i hilus, og egner seg bedre til differensiering mellom aterosklerotiske og ikke-aterosklerotiske forandringer (17). Til MR-angiografi benyttes ikke potensielt nefrotoksisk kontrastmiddel.

\section{Behandling}

Behandlingen rettes mot normalisering av blodtrykket ved hjelp av medikamenter eller ved revaskularisering. Tilfeldige funn av fibromuskulær dysplasi skal ikke behandles, men blodtrykket bør følges årlig av lege. For behandling av hypertensjon er ACE-hemmere eller angiotensin II-reseptorblokkere foretrukket førstevalg. Siden disse medikamentene kan påvirke nyrefunksjonen hos pasienter med nyrearteriestenose, bør serum-kreatinin kontrolleres hyppig i starten og deretter årlig (14). For øvrig vil ikke medikamentell behandling skille seg fra annen hypertensjonsbehandling. En metaanalyse som inkluderte over 2600 pasienter med renal fibromuskulær dysplasi, viste at perkutan revaskularisering med angioplastikk kunne normalisere blodtrykket hos $45,7 \%$ av pasientene (18). Det finnes ingen randomiserte kontrollerte studier som har sammenlignet effekten av revaskularisering og medikamentell behandling alene. Likevel anbefales perkutan angioplastikk ved hypertensjon og fibromuskulær dysplasi dersom man ikke oppnår tilfredsstillende blodtrykkskontroll med tre eller flere medikamenter (19).

I motsetning til ved aterosklerotisk nyrearteriestenose er det ingen holdepunkter for å anbefale stenting ved fibromuskulær dysplasi, med mindre det oppstår komplikasjoner under det revaskulariserende inngrepet (20). Tromboseforebygging med acetylsalisylsyre bør tilbys i minimum én måned postoperativt. Åpen kirurgi er svært sjelden nødvendig.

\section{Videre oppfølging}

Pasienter med fibromuskulær dysplasi må følges individuelt avhengig av blodtrykk, eventuelle andre symptomer og resultat av medikamentell eller revaskulariserende behandling.

Etter revaskulariserende inngrep anbefaler vi kontroll av blodtrykk hos spesialist innen den første måneden. Ofte kan antihypertensiver reduseres eller seponeres. Eventuelle restenoser manifesterer seg erfaringsmessig innen de første seks månedene etter inngrepet. Aktuelle undersøkelser ved residiv av hypertensjon er ultralyd med doppler eller gjentatt angiografi av arterien.

Både med og uten perkutan angioplastikk er det viktig å følge pasientens blodtrykk og nyrefunksjon med årlig estimering av serum-kreatinin samt bedømming av nyrestørrelsen med ultralyd (19). Stabile pasienter kan følges i primærhelsetjenesten.

\footnotetext{
LITTERATUR:

1. Leadbetter WF, Burkland CE. Hypertension in unilateral renal disease. J Urol 1938; 39: 611-26.

[CrossRef]

2. Olin JW, Froehlich J, Gu X et al. The United States Registry for Fibromuscular Dysplasia: results in the first 447 patients. Circulation 2012; 125:3182-90. [PubMed][CrossRef]

3. Plouin PF, Baguet JP, Thony F et al. High prevalence of multiple arterial bed lesions in patients with fibromuscular dysplasia: The ARCADIA Registry (Assessment of Renal and Cervical Artery Dysplasia). Hypertension 2017; 70: 652-8. [PubMed][CrossRef]

4. Plouin PF, Perdu J, La Batide-Alanore A et al. Fibromuscular dysplasia. Orphanet J Rare Dis 2007; 2: 28. [PubMed][CrossRef]
} 
5. McKenzie GA, Oderich GS, Kawashima A et al. Renal artery fibromuscular dysplasia in 2,640 renal donor subjects: a CT angiography analysis. J Vasc Interv Radiol 2013; 24: 1477-8o. [PubMed][CrossRef]

6. Persu A, Touzé E, Mousseaux E et al. Diagnosis and management of fibromuscular dysplasia: an expert consensus. Eur J Clin Invest 2012; 42:338-47. [PubMed][CrossRef]

7. Saarinen HJ, Palomäki A. Acute renal infarction resulting from fibromuscular dysplasia: a case report. J Med Case Reports 2016; 10: 118. [PubMed][CrossRef]

8. Rushton AR. The genetics of fibromuscular dysplasia. Arch Intern Med 1980; 140: 233-6. [PubMed][CrossRef]

9. Sang CN, Whelton PK, Hamper UM et al. Etiologic factors in renovascular fibromuscular dysplasia. A case-control study. Hypertension 1989; 14: 472-9. [PubMed][CrossRef]

10. Kiando SR, Tucker NR, Castro-Vega LJ et al. PHACTR1 is a genetic susceptibility locus for fibromuscular dysplasia supporting its complex genetic pattern of inheritance. PLoS Genet 2016; 12: e1006367. [PubMed][CrossRef]

11. Ganesh SK, Morissette R, Xu Z et al. Clinical and biochemical profiles suggest fibromuscular dysplasia is a systemic disease with altered TGF- $\beta$ expression and connective tissue features. FASEB J 2014; 28:3313-24. [PubMed][CrossRef]

12. Savard S, Azarine A, Jeunemaitre X et al. Association of smoking with phenotype at diagnosis and vascular interventions in patients with renal artery fibromuscular dysplasia. Hypertension 2013; 61: 1227-32. [PubMed][CrossRef]

13. Persu A, Van der Niepen P, Touzé E et al. Revisiting Fibromuscular Dysplasia: Rationale of the European Fibromuscular Dysplasia Initiative. Hypertension 2016; 68: 832-9. [PubMed][CrossRef]

14. Olin JW, Gornik HL, Bacharach JM et al. Fibromuscular dysplasia: state of the science and critical unanswered questions: a scientific statement from the American Heart Association. Circulation 2014; 129: 1048-78. [PubMed][CrossRef]

15. Beregi JP, Louvegny S, Gautier C et al. Fibromuscular dysplasia of the renal arteries: comparison of helical CT angiography and arteriography. AJR Am J Roentgenol 1999; 172: 27-34. [PubMed][CrossRef]

16. Willoteaux S, Faivre-Pierret M, Moranne O et al. Fibromuscular dysplasia of the main renal arteries: comparison of contrast-enhanced MR angiography with digital subtraction angiography. Radiology 2006; 241: 922-9. [PubMed][CrossRef]

17. Vasbinder GB, Nelemans PJ, Kessels AG et al. Accuracy of computed tomographic angiography and magnetic resonance angiography for diagnosing renal artery stenosis. Ann Intern Med 2004; 141: 674-82, discussion 682. [PubMed][CrossRef]

18. Trinquart L, Mounier-Vehier C, Sapoval M et al. Efficacy of revascularization for renal artery stenosis caused by fibromuscular dysplasia: a systematic review and meta-analysis. Hypertension 2010; 56: 525-32. [PubMed][CrossRef]

19. Persu A, Giavarini A, Touzé E et al. European consensus on the diagnosis and management of fibromuscular dysplasia. J Hypertens 2014; 32: 1367-78. [PubMed][CrossRef]

20. Raju MG, Bajzer CT, Clair DG et al. Renal artery stent fracture in patients with fibromuscular dysplasia: a cautionary tale. Circ Cardiovasc Interv 2013; 6: e30-1. [PubMed][CrossRef]

Publisert: 19. februar 2019. Tidsskr Nor Legeforen. DOI: 10.4045/tidsskr.18.0226

Mottatt 8.3.2018, første revisjon innsendt 2.8.2018, godkjent 20.11.2018.

(C) Tidsskrift for Den norske legeforening 2020. Lastet ned fra tidsskriftet.no 